International Journal of Current Microbiology and Applied Sciences

ISSN: 2319-7706 Volume 9 Number 7 (2020)

Journal homepage: http://www.ijcmas.com

Original Research Article

https://doi.org/10.20546/ijcmas.2020.907.347

\title{
Comparative Assessment of Indicators of Local Varieties of Amaranth Seeds with Cereal Crops
}

\author{
Rafik Amonovich Makhmudov*, Kahramon Halimovich Majidov, \\ Kuvondik Yunusovich Makhmudov and Feruza Amonovna Bozorova
}

Bukhara Engineering-Technological Institute, Bukhara, Republic of Uzbekistan

*Corresponding author

\section{A B S T R A C T}

\section{Keywords \\ Amaranth seeds, Chemical composition, \\ Biological components, Fatty acids, Enzyme effects \\ Article Info \\ Accepted: \\ 22 June 2020 \\ Available Online: \\ 10 July 2020}

\section{Materials and Methods}

Modern methods of physical and chemical analysis have been used to determine the chemical composition of amaranth seeds (Kazakov, 1983). Amino-acid composition of proteins and content of fatty acids were determined by chromatographic analysis (Shcherbakov, 1989; Kretovich, 1986; Inform. bulletin, RAAS, 1994; Poznyakovsky, 2005). Nutritional value was 
established by content of constituent components (Wagenfeld, 1994; Oaxtepec, 1991; Sun, 1995; Uriapongson, Rayas-Duarte, 1994).

\section{Results and Discussion}

Recently, special attention has been paid to the efficient and rational use of nontraditional plant crops. In this direction, amaranth seeds with the content of biological active components in their composition are of great importance.

\section{Purpose of the work}

Study of technological methods for extracting oil from seeds of local amaranth varieties.

Amaranth seeds are of particular importance among such crops, (Uriapongson, RayasDuarte, 1994; Andrusev, 2000), the sowing of which in the republic is increasing annually.

In this regard, scientific and practical research in this area has scientific and practical interest.

Innovative technologies for extracting vegetable oil from local varieties of amaranth seeds have been studied in work.

Methods of pressing and extraction are the most effective technology for extracting oils from these types of raw materials. Considering this, four methods of seed preparation in laboratory conditions were studied: 1- amaranth seeds were finely crushed in laboratory mill; 2- amaranth seeds were crushed by leafing on stand single-pair roller mill; 3- amaranth seeds were subjected to heat and moisture treatment with leading moisture content to $10-12 \%$ and temperature to $100-105{ }^{\circ} \mathrm{C}$, followed by leafing on singlepair roller mill; 4- seeds were crushed on roller mill through three passes, subjected to heat and moisture treatment and leafed on single-pair roller mill. Moisture and heat treatment was carried out with saturated steam in autoclave.

Dependence of porosity coefficients of the petals on their moisture (Fig. 1) is represented by group of converging straight lines, the intersection point of which corresponds to moisture (at a temperature of $100-105{ }^{\circ} \mathrm{C}$ ), equal to about $14 \%$, at which elastic effect is practically absent, i.e. at the indicated moisture and temperature, the petal behaves like a plastic body.

According to the kinetic curves of extraction, it was defined that oil is effectively extracted from the amaranth petal obtained by crushing seeds, their heat and moisture treatment at a temperature of $100-105{ }^{\circ} \mathrm{C}$ and a humidity of $10-12 \%$, followed by leafing on roller mill with a roll gap of $0.2-0.9 \mathrm{~mm}$. In the filter cake obtained by extracting petal according to effective preparation variant, particle fraction of 10-22 $\mu \mathrm{m}$ predominates, while in the filter cake without moisture-thermal treatment, particle fraction of 2 to $5 \mu \mathrm{m}$ prevails, corresponding to the results of studying the cellular structure of the grain size of starch, which confirms the effectiveness of the $1^{\text {st }}$ option.

At selected optimal conditions for preparation of amaranth seeds, quality of oil is stabilized because of the inactivation of dipole enzymes (Table 1).

Based on the properties of localization of oil and protein in the embryonic peripheral part of amaranth seeds, it is possible to increase the efficiency of processing with separation of shell and embryo by grinding the amaranth seeds and subsequent separation of crushed mass into two fractions: the perderm, containing mainly starch and enriched with oil and protein. Their ratio is $60-63 \%$ and $35-$ $40 \%$, respectively, when sifting on a sieve with diameter of hole of $0.5 \mathrm{~mm}$; large 
(descent) fraction contains average $3.4 \%$ lipids, $10.5 \%$ protein; the fine (pass through a sieve) fraction contains an average of $14.5 \%$ lipids and $29.9 \%$ protein.

Choosing the most promising directions of processing of amaranth seeds, including the stage of cleaning before grinding, the physical and mechanical parameters of seeds were studied, and it was established that seeds of amaranth of "Aztec" variety (13.Dubonosov, Guseva, 1991) are better, because they exceed in size, volume mass and weight of 1000 pieces than seeds of "Uzbekistan" variety (Zheleznov, 1991).

Organoleptic properties are of great technological importance, because the taste and colour of amaranth seeds affect the quality of flour during their processing without separation of the shell, therefore in the development of functional products "Aztec" variety with uniform light color of seeds without pigmentation, without pronounced herbaceous taste and smell is preferable (15).

Considering the use of amaranth seeds as a source of essential macro and micro components in functional products and BAA, their specific biological features compared to traditional food crops were identified (Tables 2 and 3 ).

Research have established that microelements (manganese, copper, iron) and macroelements: potassium, calcium, phosphorus, magnesium, sodium (Table 3) are present in the seed composition.

Functionally significant is the content of calcium (30 times more than in corn and 15 times more than in wheat) and phosphorus $(0.57 \%)$, which are in the optimal ratio (1:2), favorable for assimilation by the human body. Research has shown that the best balance in amino-acid composition is the distinctive feature of amaranth seeds (table 4). Taking into account unique composition of amaranth seeds, expediency of their use in development of new products without isolation of separate most valuable components, including lipids was considered.

Significant contribution to the formation of the functional direction of the products is made by the lipid complex, the ratio of the separate components in which determines its nutritional benefits and physiological value (Table 5).

The uniqueness of amaranth oil, its functional importance, both as independent product and in the composition of created BAA, is determined by biologically active substances such as squalene, tocopherols, phytosterols, carotenoids, phospholipids, as well as polyunsaturated fatty acids.

The fatty acid composition of lipids isolated from amaranth seeds was studied (Table 6).

It can be concluded that the studied amaranth oil refers to vegetable oils of the linoleic group $(50 \%)$ with a high content of palmitic $(18-19 \%)$ and oleic (22\%) acids.

The effectiveness of the lipid component can be sufficient to achieve its specific functional effect in complex with other BAA of seeds using light-colored seeds prepared in the form of flour (16-18).

It has been established that amaranth seeds of various varieties can be a source of starch (61.40-61.70\%) and protein (14.90-17.25\%) balanced in amino-acid composition. By the amount of lysine, amaranth corresponds to soybean, exceeds wheat and corn; by the amount of methionine exceeds maize and soybean by two times and wheat by three times. Phenylalanine and trozine in amaranth seeds are 1.7 times higher than in corn, wheat and soybean. 
Fig.1 Dependence of porosity coefficient $(\mathrm{K})$ on the moisture content $(\mathrm{W})$ of the petals for various values of the gap between the rollers:

$$
1 \text { - } 0.9 \mathrm{~mm} ; 2 \text { - } 0.4 \mathrm{~mm} ; 3 \text { - } 0.5 \mathrm{~mm}
$$

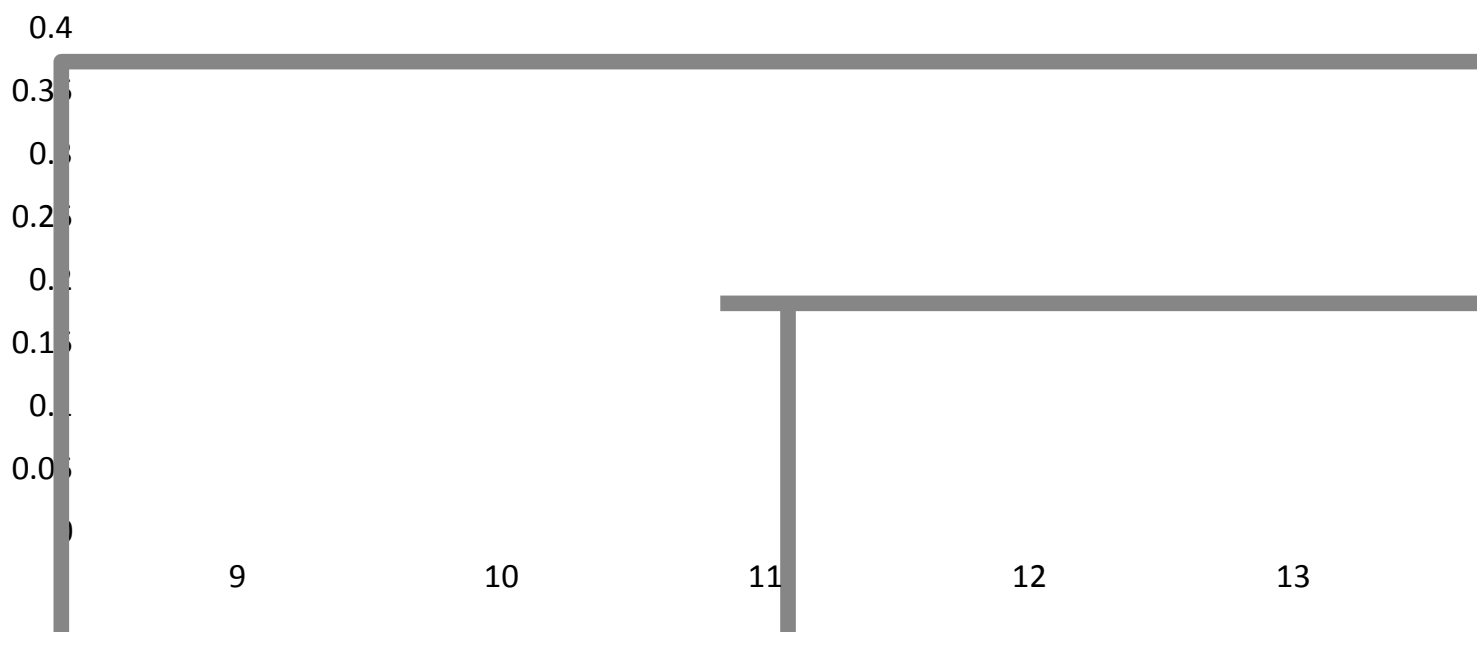

Table.1

\begin{tabular}{|c|c|c|c|}
\hline \multirow[t]{2}{*}{ Indicators } & \multirow{2}{*}{$\begin{array}{l}\text { Initial pressed } \\
\text { mass }\end{array}$} & \multicolumn{2}{|c|}{ Type of processing } \\
\hline & & Thermal & Hydrothermal \\
\hline $\begin{array}{l}\text { Initial temperature of } \\
\text { pressed mass, }{ }^{\circ} \mathrm{C}\end{array}$ & 20 & 20 & 20 \\
\hline $\begin{array}{l}\text { Final temperature of } \\
\text { pressed mass, }{ }^{\circ} \mathrm{C}\end{array}$ & 20 & 105 & 105 \\
\hline $\begin{array}{l}\text { Initial moisture of pressed } \\
\text { mass, }\end{array}$ & 9.2 & 9.2 & 12.2 \\
\hline $\begin{array}{l}\text { Final moisture of pressed } \\
\text { mass }\end{array}$ & 9.2 & 4.6 & 8.7 \\
\hline $\begin{array}{l}\text { Acid number of oil, mg } \\
\text { KOH/g }\end{array}$ & 8.2 & 9.6 & 3.7 \\
\hline
\end{tabular}

Table.2 Composition of basic nutrients of "Aztec" variety amaranth seeds and traditional cereals, $\%$

\begin{tabular}{|c|c|c|c|c|}
\hline Name of the indicator & Amaranth & Corn & Wheat & Soy \\
\hline Protein & $17.25 \pm 0.35$ & 13.08 & 15.07 & 43.67 \\
(N x6.25) & $7.05 \pm 0.14$ & 6.12 & 3.07 & 21.18 \\
Lipids & $61.40 \pm 0.26$ & 74.35 & 66.56 & 4.17 \\
Starch & $3.33 \pm 0.08$ & 1.74 & 1.68 & 12.14 \\
Mono- and disaccharides & $7.36 \pm 017$ & 2.61 & 11.76 & 12.31 \\
Dietary fibers & $3.61 \pm 0.13$ & 2.10 & 1.86 & 6.53 \\
\hline Mineral substances & & & & \\
\hline
\end{tabular}


Table.3 Mineral composition of "Aztec" variety amaranth seeds in comparison with known grain crops, \%

\begin{tabular}{|c|c|c|c|c|}
\hline Name of the element & Amaranth & Corn & Wheat & Soy \\
\hline $\begin{array}{c}\text { Macro-elements, \% } \\
\text { calcium }\end{array}$ & 0.30 & 0.01 & & \\
phosphorus & 0.57 & 0.27 & 0.02 & 0.35 \\
magnesium & 0.34 & 0.13 & 0.10 & 0.60 \\
potassium & 0.53 & 0.48 & 0.40 & 0.23 \\
$\begin{array}{c}\text { sodium } \\
\text { Microelements, }\end{array}$ & 0.26 & 0.01 & 0.01 & 0.04 \\
mg/100g & & & & \\
copper & 4.10 & 4.00 & 4.20 & 0.50 \\
manganese & 5.20 & 7.00 & 28.00 & 2.80 \\
\hline
\end{tabular}

Table.4 The content of essential amino-acids of the seeds of "Aztec" variety amaranth and traditional crops, $\mathrm{g} / 100 \mathrm{~g}$ protein

\begin{tabular}{|c|c|c|c|c|}
\hline Name of amino-acid & Amaranth & Corn & Wheat & Soy \\
\hline $\begin{array}{c}\text { Phenylalanine + } \\
\text { tyrosine }\end{array}$ & 7.0 & 4.1 & 4.1 & 4.0 \\
Lysine & 6.2 & 5.9 & 2.5 & 2.7 \\
Leucine & 5.7 & 7.1 & 6.6 & 9.5 \\
Valine & 4.3 & 4.5 & 3.0 & 3.4 \\
Methionine & & & & \\
+ cystine & 4.2 & 1.9 & 1.3 & 2.4 \\
Isoleucine & 3.7 & 4.5 & 2.4 & 2.3 \\
Threonine & 3.6 & 3.4 & 3.0 & 3.4 \\
$\begin{array}{c}\text { Tryptophan } \\
\text { Total essential amino- }\end{array}$ & 1.5 & 1.7 & 1.2 & 0.9 \\
acids & 36.2 & 33.1 & 24.1 & 38.2 \\
\hline
\end{tabular}

Table.5 Nutritional value of amaranth oil

\begin{tabular}{|c|c|}
\hline Composition components & Characteristic and value of the indicator \\
\hline Triglycerides, $\mathbf{g}$ & $75.0-79.0$ \\
Squalene, $\mathbf{g}$ & $7.9-8.1$ \\
Phospholipids, $\mathbf{g}$ & $9.0-11.0$ \\
Phytosterols, $\mathbf{g}$ & $3.4-3.8$ \\
Total tocopherols, $\mathbf{m g}$ & $190-210$ \\
Carotenoids, $\mathbf{m g}$ & $0.3-0.5$ \\
\hline
\end{tabular}


Table.6 Fatty acid composition of amaranth

\begin{tabular}{|c|c|}
\hline Name of acid & Content, \% to the total of fatty acids \\
\hline Myristine & 0.14 \\
Pentadecane & 0.88 \\
Palmitic & 18.59 \\
Margarine & 1.37 \\
Stearin & 4.45 \\
Arachic & 0.27 \\
Docosanic & 0.24 \\
Tetracosanic & 0.08 \\
Palmitinolein & 0.08 \\
Oleic & 22.69 \\
Linoleic & 48.00 \\
a-linolenic & 0.35 \\
- linolenic & 0.92 \\
Eicosenic & 1.49 \\
Docosenic & 0.7 \\
Nervonoic & 0.54 \\
\hline
\end{tabular}

Amaranth oil is unique because of content of squalene, the concentration of which depends on the seeds being of a certain variety (whiteseed, pink-seed or black-seed) and varies from 6.37 to $8.50 \%$. The most biologically active components present in amaranth seed lipids are: sterols (3.70-4.60\%), carotenoids (0.3-0.5 mg\%), tocopherols $(0.13-0.18 \%)$. It was established that the lipids of amaranth seeds are stabilized by tocopherols with high antioxidant activity: $\beta,-\gamma,-$ and $\delta$-isomers, the total content of which reaches $93 \%$.

By the composition of fatty acids, amaranth oil extracted from seeds of the "Aztec" variety belongs to the group of linoleic acid (up to $50 \%$ of the total of fatty acids), and the content of the most biologically active linolenic acid reaches $1 \%$.

Thus, in terms of the content of macroelements: calcium, amaranth seeds exceed corn 30 times, wheat 15 times; phosphorus approach soybean, corn 2 times, wheat 1.4 times; magnesium and sodium are superior to both true and false cereals.
Conclusion is as follows:

Research carried outallow establishing optimal modes and methods for preparing structure of material in terms of efficiency of oil extraction from amaranth seeds and subsequent filtration of micelle, as well as stabilization of oil quality.

Comparative assessment of the main nutrients and mineral composition of amaranth seeds with traditional crops showed that amaranth seeds are unique raw material for the production of biologically active additives (BAA). In terms of protein content, amaranth seeds are superior to all spread crops, second only to legumes; in terms of lipid content amaranth exceeds corn and wheat, and is less than soybean (3.0 times).

\section{References}

Amaranth protein fortifiers for the production of special products / Inform. bulletin, RAAS, STC and Agropischeprom. ARRIAH. St. Petersburg: 1994. 
Amaranth. Nene Aussichten FuerEine Alte Wunderpflanze. Hastenpflug M. (Red). Wagenfeld, $1994.36 \mathrm{~s}$

Andrusev A.A. Amaranth is a good culture / A.A. Andrusev // Potatoes and vegetables. - 2000. - No. 5. - p.20.

Chemical composition of food products // Ed. by Skurikhin I.M. M.: Light and food industry. -1984 , p. 325

Dubonosov T., Guseva T. How to grow amaranth / T. Dubonosov, T. Guseva // Niva Kuban. 1991. - No. 16. - p. 1012.

Fedotov V.A. Crop production: Practicum / V.A. Fedotov, V.V. Kolomeychenko et al., Voronezh: Publishing house of Voronezh University, 1996, p. 392.

Kazakov E.D. Grain science with the basics of crop production. $3^{\text {rd }}$ ed., revised and added. M.: Kolos, 1983, p. 352: ill.

Klyuchkin V.V. Food products from seeds of lupine and amaranth / V.V. Klyuchkin // Oil and fat industry. 1999. - No. 1, p. 20-22.

Kochetkova A.A. The modern theory of positive nutrition in functional products / Kochetkova A.A., KolesnikovA.Yu. // Food industry.
1999. - No. 4. - p. 9-10.

Kretovich B.L. Biochemistry of plants. M.: High school, 1986, p. 503: ill.

Poznyakovsky V.M. Food and biologically active additives / V.M. Poznyakovsky, A.N. Avstrievskih, A.A. Vekovtsev. $2^{\text {nd }}$ ed., revised and added - MoscowKemerovo: Publishing Association "Russian Universities", 2005. p. 275.

Primer Congreso Internetionaldel Amaranto. Oaxtepec, $1991.132 \mathrm{p}$

Shcherbakov V.G., Ivanitsky S.B. Production of protein products from oilseeds. -M.: Agropromizdat, 198, p.152.

Sun H., ect. Bench-Scale Processing of amaranth for oil / Inform-1995.- v.6.No 4.- p. 489

Uriapongson J., Rayas-Duarte P. Comparison of yield and properties of amaranth. // Cereal Chem.-1994/71, No. 6. - p. 571-577

Zheleznov A.B. Proteins of seeds of wildgrowing and cultivated species of amaranth / A.B. Zheleznov, L.P. Solonenko, N.B. Zheleznova // Genetics of cultivated plant species. Novosibirsk 1991. - p. 234-250.

\section{How to cite this article:}

Rafik Amonovich Makhmudov, Kahramon Halimovich Majidov, Kuvondik Yunusovich Makhmudov and Feruza Amonovna Bozorova. 2020. Comparative Assessment of Indicators of Local Varieties of Amaranth Seeds with Cereal Crops. Int.J.Curr.Microbiol.App.Sci. 9(07): 2944-2950. doi: https://doi.org/10.20546/ijcmas.2020.907.347 